\title{
Factors Affecting Medical Equipment Management in the COVID-19 Pandemic Crisis: A Mixed Qualitative and Quantitative Study
}

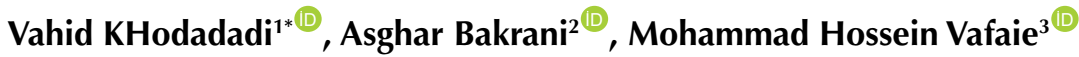 \\ ${ }^{1}$ Department of Biomedical Engineering, Science and Research Branch, Islamic Azad University, Tehran, Iran \\ ${ }^{2}$ Department of Medical Engineering, Raghib Isfahani Institute of Higher Education, Isfahan, Iran \\ ${ }^{3}$ Medical Image \& Signal Processing Research Center, School of Advanced Technologies in Medicine, Isfahan \\ University of Medical Sciences, Isfahan, Iran
}

*Corresponding Author: Vahid Khodadadi, Ph.D. in Biomedical Engineer, Department of Medical Engineering, Faculty of Medical Sciences and Technologies, Islamic Azad University, Science and Research Branch, Tehran, Iran. Email: bmevahid@yahoo.com

Received January 7, 2021; Accepted January 20, 2021; Online Published February 13, 2021

\begin{abstract}
Background: Medical equipment plays an important role in community health in critical situations such as the COVID-19 pandemic. Objectives: This study was conducted to determine and identify the factors affecting the management of medical equipment in crisis situations.

Methods: The present study was conducted as a mixed qualitative and quantitative study in 2020. In the qualitative section using the targeted sampling method, ten medical equipment management experts and in the quantitative section using available sampling method, 200 managers and experts active in this field from hospitals and related companies were selected for this study. The qualitative part was conducted in two stages of reviewing texts and interviewing experts and in the quantitative part we evaluated the validity of the structure and the reliability of the questionnaire.

Results: The validity of the structure was assessed using heuristic factor analysis. KMO index was 0.971 and Bartlett test was significant $(P<0.05)$. All six approved components in the content validity section, based on the mathematical model, explain and determine more than $77 \%$ of the variance related to the purpose of the study which is the management of medical equipment in COVID-19 pandemic situations.

Conclusion: The results showed that the instructions, management, information technology, equipment, manpower, and physical space components had the highest and lowest priority in the management of medical equipment in critical situations, respectively. In this regard, appropriate instructions should be provided first and localized protocols should be communicated from the same source at the same time.
\end{abstract}

Keywords: Equipment and Supplies, Risk Management, COVID-19

\section{Background}

A crisis is an event that occurs suddenly and sometimes increasingly and leads to a dangerous and unstable situation for an individual, group, or community ${ }^{1}$ and causes a situation that requires fundamental and extraordinary measures to resolve. Crises are usually unpredictable, but usually not unexpected, except for natural disasters that cause crises; they are more of an emergency and a moment to become a permanent state. ${ }^{2-4}$

Although the timing of crises is not completely predictable, it can be managed using previous experience. In fact, if the critical situation is already researched and its critical problems and challenges are evaluated and analyzed, some problems would not occur in future crises. Although crises are not the same, the nature of their management is similar. Therefore, if the conditions of a crisis such as the COVID-19 pandemic and all its relevant challenges are evaluated and examined, these results can be used in subsequent crises. ${ }^{5,6}$

There are different types of crises, including personal crisis, social crisis, economic crisis, political crisis, international crisis and environmental crisis. ${ }^{7}$ What is most evaluated in this study are the crises that often challenge health systems, although it should be noted that most of the crises that have occurred in the world have not been ineffective on health systems. Among the previously mentioned crises, we can mention the latest crisis in the world, the COVID-19 pandemic. COVID-19 is a pandemic that has challenged the world in all aspects of economics, medicine, medicine, equipment, etc. ${ }^{8}$

COVID-19 started as an environmental crisis in Wuhan, China, in 2020 and affected the entire world in less than

Copyright $\odot 2021$ The Author(s). This is an open-access article distributed under the terms of the Creative Commons Attribution License (http:// creativecommons.org/licenses/by/4.0), which permits unrestricted use, distribution, and reproduction in any medium, provided the original work is properly cited. 
six months. Patients with COVID-19 needed special units with assisted equipment due to respiratory problems. It should be noted that due to the rapid spread of this disease, the capacity of consumer equipment, capital, and even active special wards of the hospital did not respond to the need for crisis and the crisis has become more severe..$^{9-14}$

To deal with this epidemic in terms of medical equipment, the management of two groups is required. The first group was medical equipment used as personal protection for medical personnel and members of the community to prevent the transmission of the virus ${ }^{15-19}$ and the second group was related to medical equipment and adjuvant therapy that was used to treat patients. Among these equipment, we can mention various types of ventilators, monitors, thermometers, and all equipment of the intensive care unit, etc. ${ }^{20}$

\section{Objectives}

The onset of an epidemic in the world will affect all manufacturers and distributors of medical equipment and lead to problems such as shortages, significant price increases, the formation of groups or profiteers, etc. ${ }^{21}$ This study, therefore, aims to collect information from all hospitals, health centers, manufacturing companies, distributors, and all institutions involved in the management of medical equipment and analyze this information to create a management strategy to control the crisis of medical equipment in future crises and resolve the previous problems occurred.

\section{Methods}

\subsection{Study Design}

The present study is an analytical-applied and crosssectional study conducted as a mixed qualitative and quantitative study in Iran in 2020.

\subsection{Study Population}

The target community of the quality department includes all university professors and experts with teaching experience or activity of more than ten years in the field of accident management and medical equipment engineering with specialized education in the field of medical engineering and its quantity counterpart consisted of a small number of managers and experts active in hospitals and public and private medical equipment companies.

\subsection{Sampling Size}

In the qualitative part, using purposive sampling method and snowball until saturation of opinions, and in the quantitative part, using the available sampling method and based on Krejcie \& Morgan sample size determination table, ${ }^{22} 10$ and 200 people were respectively selected to enter the study.

\subsection{Method of Implementation (Qualitative Part)}

The qualitative part of the present study was conducted in two stages. In the first stage, the method of library study and systematic review was used. Persian and English articles and books from domestic and foreign databases such as Elsevier, Scopus, PubMed, Medline, IranMedex, IranDoc with the help of Google Scholar search engines and search for official reports in information sources of national and international organizations such as AHRO, WHO, NHS, ICAHO was thoroughly evaluated. After ensuring the complete search and saturation of the collected information, the content analysis method was used to encode, classify, and conclude the obtained information.

Finally, the variables affecting the management of medical equipment in critical situations were identified as a conceptual model in the form of six components of manpower, physical space, equipment, management, information technology, and instructions. In the second stage, to determine the status of each component in the COVID-19 pandemic crisis, the Delphi technique and interviews with experts were used. In this way, a conceptual model was provided to the experts for evaluation. Experts' opinions on adding, modifying, and reviewing various components and sections and determining the variables affecting them in the context of the COVID-19 pandemic crisis were collected in three round-trip stages. A questionnaire was provided to the experts to evaluate the content validity using content validity ratio (CVR) and content validity index $(C V I)$ indicators. The CVR index in all items was higher than 0.8 and the CVI index in all components, as well as the whole questionnaire, was higher than 0.9. Finally, the content validity of the researcher-made questionnaire for the management of medical equipment in the COVID-19 pandemic crisis was confirmed (Table 1).

\subsection{Method of Implementation (Quantitative Part)}

Due to the fact that the researcher-made questionnaire was approved by experts in terms of content validity, it is necessary to evaluate the construct validity and reliability. To this end, 200 members of the target community were selected using the available sampling method and completed a questionnaire. Cronbach's alpha index was used to determine the reliability and an exploratory factor analysis technique was employed to determine the construct validity.

\subsection{Data Collection Tools}

The researcher-made questionnaire in this study includes 24 items in 6 structures (dimension) in which the measurement scale of each item was determined by five-choice Likert scale (very low $=1$, very high=5). The dimensions of the questionnaire also included manpower, physical space, equipment, management, information technology, and instructions.

\subsection{Statistical Analysis}

After collecting the questionnaires, exploratory factor analysis was used to evaluate the construct validity and Cronbach's alpha index was used to determine the reliability 
Table 1. Researcher-Made Questionnaire After Confirming the Content Validity

\begin{tabular}{|c|c|}
\hline Component & Factors \\
\hline Manpower & $\begin{array}{l}\text { Manpower training, how to use the equipment properly, matching the number of equipment with the number of patients, } \\
\text { commitment to the device }\end{array}$ \\
\hline Physical space & $\begin{array}{l}\text { Equipment storage location, equipment layout, suitable trolleys for transporting equipment, the existence of suitable physical } \\
\text { facilities and infrastructure, keeping the device clean }\end{array}$ \\
\hline Management & Supply or purchase management, price management, resource distribution management, liabilities, producer management \\
\hline Equipment & High precision equipment (calibrated), standard equipment \\
\hline Instructions & Types of instructions and protocols, method of notification, time of notification, notifying authority, unity of instructions \\
\hline Information technology & Integrated communication systems, online equipment registration system, information \\
\hline
\end{tabular}

of the dimensions and that of the whole questionnaire. All statistical analyses were performed by SPSS software version 21. The significance level of statistical tests was considered to be $5 \%$.

\section{Results}

In the present study, 200 people were included in the study by available methods, $60 \%$ of whom were men. Fifteen point nine percent of the participants were under 30 years old, $46.6 \%$ were in the age range of 31 to 40 years and $37.5 \%$ were over 40 years old. $47.5 \%$ of the participants had a master's degree, $21.6 \%$ had a professional doctorate, and $16.6 \%$ had a PhD (Table 2).

In performing exploratory factor analysis, first, the KMO index or the adequacy index of sampling and Bartlett's test was evaluated. The KMO index is used to check small partial correlations between variables. In this study, the KMO index of 0.971 was obtained, which indicates the appropriateness of the information as well as the number of variables of each structure for exploratory factor analysis. Bartlett's test was also obtained in this study $(P<0.05)$ showing that heuristic factor analysis is suitable for identifying the structure (factor model) (Table 3 ).

The results showed that the constructs designed in the researcher-made questionnaire from library studies and systematic review, as well as the opinion of experts based on the mathematical model, justify more than $77 \%$ of the variance related to the purpose of the study, i.e. medical equipment management in COVID-19 crisis. In other words, the questionnaire has the necessary capability to evaluate the management of medical equipment in the event of a COVID-19 crisis and can be cited. Therefore, this result confirms the validity of the structure (Table 4). According to the obtained results, manpower and information technology showed the most and the least amount of variance in the structure of medical equipment management in COVID-19 crisis conditions, respectively (Table 4).

Reliability evaluation showed that all constructs and the whole questionnaire had a Cronbach's alpha greater than 0.7. In other words, reliability in the target population shows that the researcher-made questionnaire has good reliability, stability, accuracy, and reliability (Table 5).

Finally, in the target population, the study prioritized each of the factors affecting the management of medical equipment in the COVID-19 pandemic crisis. According to the answers to the questions, the instruction component and then the management component had higher priority and the physical space component had the lowest priority in the management of medical equipment in critical situations (Table 6).

\section{Discussion}

With the outbreak of the COVID-19 pandemic in the world, the health sector is facing many challenges, which is one of the important areas of medical equipment. In addition to the fact that the virus persists on surfaces and can be transmitted to another person, the lack of equipment in various areas, from small consumables such as masks to heavy equipment such as ventilators has become more important.

The findings of the present study showed that the instruction component, management component, information technology component, equipment component, manpower component, and physical space component had the highest and lowest priority in managing medical equipment in critical situations, respectively. Based on this, the components of each of these factors were categorized as follows:

Managing factors affecting the management of medical

Table 2. Frequency Distribution of Study Participants

\begin{tabular}{llcc}
\hline Demographic Characteristics & Frequency & Percent \\
\hline \multirow{2}{*}{ Sex } & Female & 48 & 40 \\
& Male & 72 & 60 \\
\multirow{2}{*}{ Age } & Less than 30 years & 19 & 15.9 \\
& 30 to 40 years & 56 & 46.6 \\
& More than 40 years & 45 & 37.5 \\
\multirow{4}{*}{ Education } & B.Sc. & 10 & 8.3 \\
& M.Sc. & 57 & 47.5 \\
& M.D. & 26 & 21.6 \\
& Ph.D. & 20 & 16.6 \\
\hline
\end{tabular}

Table 3. Summary of Bartlett's Test Results and KMO Index

\begin{tabular}{lccc}
\hline \multirow{2}{*}{$\begin{array}{l}\text { KMO Measure of } \\
\text { Sampling Adequacy }\end{array}$} & \multicolumn{3}{c}{ Bartlett's Test of Sphericity } \\
\cline { 2 - 4 } & Chi-Square Statistic & df & P Value \\
\hline 0.971 & 48596.28 & 149 & 0.001 \\
\hline
\end{tabular}


Table 4. Summary of the Results of Exploratory Factor Analysis With Varimax Rotation

\begin{tabular}{|c|c|c|c|c|c|c|}
\hline Questions & Manpower & $\begin{array}{l}\text { Physical } \\
\text { Space }\end{array}$ & Management & Equipment & Instructions & $\begin{array}{l}\text { Information } \\
\text { Technology }\end{array}$ \\
\hline $\begin{array}{l}\text { To what extent is manpower training effective in managing medical } \\
\text { equipment in times of crisis? }\end{array}$ & 0.681 & & & & & \\
\hline $\begin{array}{l}\text { To what extent does the proper use of equipment affect the } \\
\text { management of medical equipment in times of crisis? }\end{array}$ & 0.682 & & & & & \\
\hline $\begin{array}{l}\text { To what extent does matching the number of equipment with the } \\
\text { number of patients affect the management of medical equipment in } \\
\text { times of crisis? }\end{array}$ & 0.635 & & & & & \\
\hline $\begin{array}{l}\text { To what extent does a sense of commitment to the device affect the } \\
\text { management of medical equipment in times of crisis? }\end{array}$ & 0.627 & & & & & \\
\hline $\begin{array}{l}\text { To what extent does the existence of appropriate physical facilities } \\
\text { and infrastructure affect the management of medical equipment in } \\
\text { times of crisis? }\end{array}$ & & 0.591 & & & & \\
\hline $\begin{array}{l}\text { To what extent is equipment arrangement effective in managing } \\
\text { medical equipment in times of crisis? }\end{array}$ & & 0.582 & & & & \\
\hline $\begin{array}{l}\text { To what extent is equipment storage effective in managing medical } \\
\text { equipment in times of crisis? }\end{array}$ & & 0.577 & & & & \\
\hline $\begin{array}{l}\text { To what extent do proper equipment transport trolleys affect the } \\
\text { management of medical equipment in times of crisis? }\end{array}$ & & 0.573 & & & & \\
\hline $\begin{array}{l}\text { To what extent does keeping the device clean affect the } \\
\text { management of medical equipment in times of crisis? }\end{array}$ & & 0.567 & & & & \\
\hline $\begin{array}{l}\text { To what extent does supply or purchase management affect the } \\
\text { management of medical equipment in times of crisis? }\end{array}$ & & & 0.532 & & & \\
\hline $\begin{array}{l}\text { To what extent do commitments affect the management of medical } \\
\text { equipment in times of crisis? }\end{array}$ & & & 0.528 & & & \\
\hline $\begin{array}{l}\text { To what extent does resource distribution management affect } \\
\text { medical equipment management in times of crisis? }\end{array}$ & & & 0.529 & & & \\
\hline $\begin{array}{l}\text { To what extent does price management affect the management of } \\
\text { medical equipment in times of crisis? }\end{array}$ & & & 0.530 & & & \\
\hline $\begin{array}{l}\text { To what extent does manufacturer management affect medical } \\
\text { equipment management in crisis situations? }\end{array}$ & & & 0.527 & & & \\
\hline $\begin{array}{l}\text { To what extent is high-calibration equipment effective in managing } \\
\text { medical equipment in crisis situations? }\end{array}$ & & & & 0.509 & & \\
\hline $\begin{array}{l}\text { To what extent is standard consumer equipment effective in } \\
\text { managing medical equipment in times of crisis? }\end{array}$ & & & & 0.504 & & \\
\hline $\begin{array}{l}\text { To what extent does the unity of guidelines affect the management } \\
\text { of medical equipment in times of crisis? }\end{array}$ & & & & & 0.631 & \\
\hline $\begin{array}{l}\text { To what extent do all kinds of instructions and protocols affect the } \\
\text { management of medical equipment in times of crisis? }\end{array}$ & & & & & 0.619 & \\
\hline $\begin{array}{l}\text { To what extent does notification time affect the management of } \\
\text { medical equipment in crisis situations? }\end{array}$ & & & & & 0.598 & \\
\hline $\begin{array}{l}\text { To what extent does the notifying authority affect the management } \\
\text { of medical equipment in times of crisis? }\end{array}$ & & & & & 0.554 & \\
\hline $\begin{array}{l}\text { To what extent does the communication method affect the } \\
\text { management of medical equipment in crisis situations? }\end{array}$ & & & & & 0.542 & \\
\hline $\begin{array}{l}\text { To what extent does information affect the management of medical } \\
\text { equipment in times of crisis? }\end{array}$ & & & & & & 0.758 \\
\hline $\begin{array}{l}\text { To what extent do integrated communication systems affect the } \\
\text { management of medical equipment in times of crisis? }\end{array}$ & & & & & & 0.596 \\
\hline $\begin{array}{l}\text { To what extent does the online equipment registration system affect } \\
\text { the management of medical equipment in times of crisis? }\end{array}$ & & & & & & 0.552 \\
\hline Cumulative Variance Percent & 21.309 & 39.299 & 53.926 & 66.291 & 72.901 & 77.346 \\
\hline \multicolumn{7}{|c|}{ Exploratory factor analysis with varimax rotation } \\
\hline
\end{tabular}


Table 5. Summary of Reliability Assessment Results

\begin{tabular}{lcc}
\hline Component & Number of Questions & Cronbach's Alpha Index \\
\hline Manpower & 4 & 0.791 \\
Physical Space & 5 & 0.731 \\
Management & 5 & 0.839 \\
Equipment & 2 & 0.855 \\
Instructions & 5 & 0.786 \\
Information Technology & 3 & 0.801 \\
Questionnaire & $\mathbf{2 4}$ & $\mathbf{0 . 8 9 0}$ \\
\hline
\end{tabular}

Table 6. Summary of Friedman Test Prioritization Results

\begin{tabular}{lccc}
\hline Component & Average Rating & Priority & P Value $^{*}$ \\
\hline Instructions & 4.2 & 1 & \\
\hline Management & 3.6 & 2 & \\
\hline Information technology & 3.1 & 3 & \multirow{2}{*}{0.001} \\
\hline Equipment & 2.3 & 4 & \\
Manpower & 1.4 & 5 & \\
\hline Physical space & 1.2 & 6 & \\
\hline
\end{tabular}

* Friedman test

equipment in critical situations include management of supply or purchase of medical equipment, management of resource distribution in hospitals and medical centers, price management, management of manufacturers, equipment approvers, and acceleration of manufacturers and obligations.

Factors affecting the management of medical equipment in critical situations include types of instructions and protocols, how and when to communicate these instructions, the notifying authority, and the unity of instructions.

Factors of physical space affecting the management of medical equipment in critical situations include equipment storage, equipment layout, suitable trolleys for transporting equipment, the existence of appropriate physical facilities and infrastructure, and keeping the device clean.

Manpower factors affecting the management of medical equipment in critical situations include training of manpower courses, how to use the equipment properly, matching the number of equipment with the number of patients, and a sense of commitment to the device.

IT factors affecting the management of medical equipment in critical situations include integrated communication systems, online equipment registration system, and information.

Factors of efficient equipment on the management of medical equipment in critical situations include highprecision (calibrated) equipment and standard equipment. In this regard, strong and coherent information systems should be provided using the latest technology, so that all equipment are systematically tracked (for maintenance and calibration).

\section{Research Highlights}

\section{What Is Already Known?}

With the outbreak of the coronavirus in the world, the health sector is facing many challenges, of which medical equipment is one of the most important areas. In addition, the lack of equipment in various sectors, from small consumer equipment such as masks to heavy equipment such as ventilators has become increasingly important.

\section{What Does This Study Add?}

The present study showed that the components instruction, management, information technology, equipment, manpower, and physical space had the highest and lowest priority in managing medical equipment in critical situations, respectively.

\section{Conclusion}

According to the research findings, the instructions, management, information technology, equipment, manpower, and physical space component had the most and the least impact on the management of medical equipment in the COVID-19 crisis, respectively. In this regard, appropriate instructions should be prepared in advance, and in case of a crisis, the Crisis Management Committee should plan and announce the management of all matters. It is suggested to use the ideas of interested students and the capabilities of knowledge-based companies in this situation. Also, the use of technology solutions such as cloud computing can be useful in using the information of medical devices and equipment.

\section{Authors' Contributions}

Study design: VK; Data collection: AB; Data analysis: VK \& MV; Manuscript writing: AB \& MV; Critical revisions: VK.

\section{Conflict of Interest Disclosures}

There was no conflict of interest in this research.

\section{Ethical Approval}

The current study was approved by Isfahan University of Medical Sciences Ethics Committee.

\section{References}

1. Lee MY, Jung WS, Oh G. The dynamics of the aggressive order during a crisis. PLoS One. 2020;15(5):e0232820. doi:10.1371/ journal.pone.0232820.

2. Bundy J, Pfarrer MD, Short CE, Coombs WT. Crises and crisis management: integration, interpretation, and research development. J Manage. 2017;43(6):1661-1692. doi:10.1177/0149206316680030.

3. Rosenthal U, Boin RA, Comfort LK. The changing world of crisis and crisis management. In: Managing Crises: Threats, Dilemmas, Opportunities. Charles C Thomas; 2001. p. 5-27.

4. Boin A. The new world of crises and crisis management: implications for policymaking and research. Rev Policy Res. 2009;26(4):367-377. doi:10.1111/j.1541-1338.2009.00389.x.

5. Duggan EAH, Appleton SG, Mikhail MM. Comment on: 
COVID-19 pandemic: perspectives on an unfolding crisis - a UK perspective. Br J Surg. 2020;107(7):e199. doi:10.1002/ bjs.11673.

6. Spinelli A, Pellino G. COVID-19 pandemic: perspectives on an unfolding crisis. Br J Surg. 2020;107(7):785-787. doi:10.1002/ bjs. 11627.

7. Vaezi M. World economic crisis: roots, dimensions and consequences. Foreign Relations. 2009;1(1):155-187. [Persian].

8. Dong L, Bouey J. Public mental health crisis during COVID-19 pandemic, China. Emerg Infect Dis. 2020;26(7):1616-1618. doi:10.3201/eid2607.200407.

9. Li H, Liu SM, Yu XH, Tang SL, Tang CK. Coronavirus disease 2019 (COVID-19): current status and future perspectives. Int J Antimicrob Agents. 2020;55(5):105951. doi:10.1016/j. ijantimicag.2020.105951.

10. Di Gennaro F, Pizzol D, Marotta C, et al. Coronavirus diseases (COVID-19) current status and future perspectives: a narrative review. Int J Environ Res Public Health. 2020;17(8):2690. doi:10.3390/ijerph17082690.

11. COVID-19 Dashboard by the Center for Systems Science and Engineering (CSSE) at Johns Hopkins University (JHU). https:// coronavirus.jhu.edu/map.html. Published July 1, 2020.

12. Gupta A, Kashte S, Gupta M, Rodriguez HC, Gautam SS, Kadam S. Mesenchymal stem cells and exosome therapy for COVID-19: current status and future perspective. Hum Cell. 2020;33(4):907-918. doi:10.1007/s13577-020-00407-w.

13. Prasad R. COVID-19: current status, challenges and future perspectives. Indian J Clin Biochem. 2020;35(4):1-2. doi:10.1007/s12291-020-00922-5.

14. Khedmat L. New coronavirus (2019-nCoV): an insight toward preventive actions and natural medicine. Int J Travel Med Glob
Health. 2020;8(1):44-45. doi:10.34172/ijtmgh.2020.07.

15. Smereka J, Szarpak L. The use of personal protective equipment in the COVID-19 pandemic era. Am J Emerg Med. 2020; 38(7):1529-1530. doi:10.1016/j.ajem.2020.04.028.

16. Tabah A, Ramanan M, Laupland KB, et al. Personal protective equipment and intensive care unit healthcare worker safety in the COVID-19 era (PPE-SAFE): an international survey. J Crit Care. 2020;59:70-75. doi:10.1016/j.jcrc.2020.06.005.

17. Klompas M, Morris CA, Shenoy ES. Universal masking in the COVID-19 era. N Engl J Med. 2020;383(2):e9. doi:10.1056/ NEJMc2020836.

18. Qi H, Chen M, Luo X, et al. Management of a delivery suite during the COVID-19 epidemic. Eur J Obstet Gynecol Reprod Biol. 2020;250:250-252. doi:10.1016/j.ejogrb.2020.05.031.

19. Liew $\mathrm{CH}$, Flaherty GT. Unmasking the myths surrounding use of barrier face coverings during the COVID-19 pandemic. Int J Travel Med Glob Health. 2020;8(4):134-136. doi:10.34172/ ijtmgh.2020.23.

20. Wang H, Wang S, Yu K. COVID-19 infection epidemic: the medical management strategies in Heilongjiang Province, China. Crit Care. 2020;24(1):107. doi:10.1186/s13054-020 2832-8.

21. Diaconu K, Chen YF, Cummins C, Jimenez Moyao G, Manaseki-Holland S, Lilford R. Methods for medical device and equipment procurement and prioritization within low- and middle-income countries: findings of a systematic literature review. Global Health. 2017;13(1):59. doi:10.1186/s12992 017-0280-2.

22. Krejcie RV, Morgan DW. Determining sample size for research activities. Educ Psychol Meas. 1970;30(3):607-610. doi:10.1177/001316447003000308 